\title{
HOUSING CHARACTER IN THE BORDER BEACH AREA OF CAMBAYYA
}

\author{
Idawarni Asmal*, Nurmaida Amri** \\ *) Architecture Departement, Engineering Faculty, Hassanudin University, \\ Indonesia \\ **) Architecture Departement, Engineering Faculty, Hassanudin University, \\ Indonesia \\ e-mail: idawarniasmal@yahoo.com
}

\begin{abstract}
Cambayya is one of the areas in the Makassar city that has slum dwellings located on the water. The houses appears sporadically due to various community problems, such as the high price of land in the Makassar city and difficult to reach by the lower classes and the desire to live near the workplace. As a result, people are looking for low-cost dwellings, although not for rationing, poor sanitation conditions, and lacking facilities and infrastructure. The purpose of this research is to know the physical and non physical character of the residence located in the area starting directly adjacent to the water body up to the Barukang road. The method used is the mix use method. In the housing study is divided into 3 zones. The first zone is in the dwelling above the water body, the 2 nd zone in the dwelling above the coastal border and, the 3rd zone is in the dormitory adjacent to the main road of the area. The data is collected through the results of field observations in depth on the physical condition of the dwelling and the community. Medium data are measured through closed questionnaires submitted randomly to communities in each zone. The result obtained is the occupancy in each zone is different because of the influence of occupation, land ownership, and location of establishment.
\end{abstract}

Keywords: Housing, character, border beach, cambayya

\section{INTRODUCTION}

Kelurahan Cambayya (Kelurahan is the lowest administrative area directly under the sub-district located at the lowest level, it is as well as of village level and is headed by a lurah, the kelurahan is also a joint area of several RW (Rukun Warga). The administrative area chosen as the survey area is RW 4. This election is based on housing conditions that appear to have a different character from the general housing in urban areas. housing in RW 4 is partly built on the coastal border area to the shallow seas. The density of population and buildings is high, it can be known from 
the calculation of population density reaching 437 people / ha and building as many as 92 units / ha.

RW 4 is a buffer zone (coastal border area) that should not be inhabited. But in fact, many homes are built in that place, even some have taken the territory of water bodies. This will have a negative impact on the aquatic environment and the view from and to the sea. The houses appear sporadically triggered by lack of land and high prices of urban land as well as low purchasing power of the community, especially for those working in the informal sector. As a result, for the people of this class will find a cheap and close residence from the workplace even though the surrounding environment is less supportive as decent and healthy dwelling.

The research location is in the north part of Makassar city, precisely in Kelurahan Cambayya RW 4. Figures 1 and 2 show the research location and the zone division.
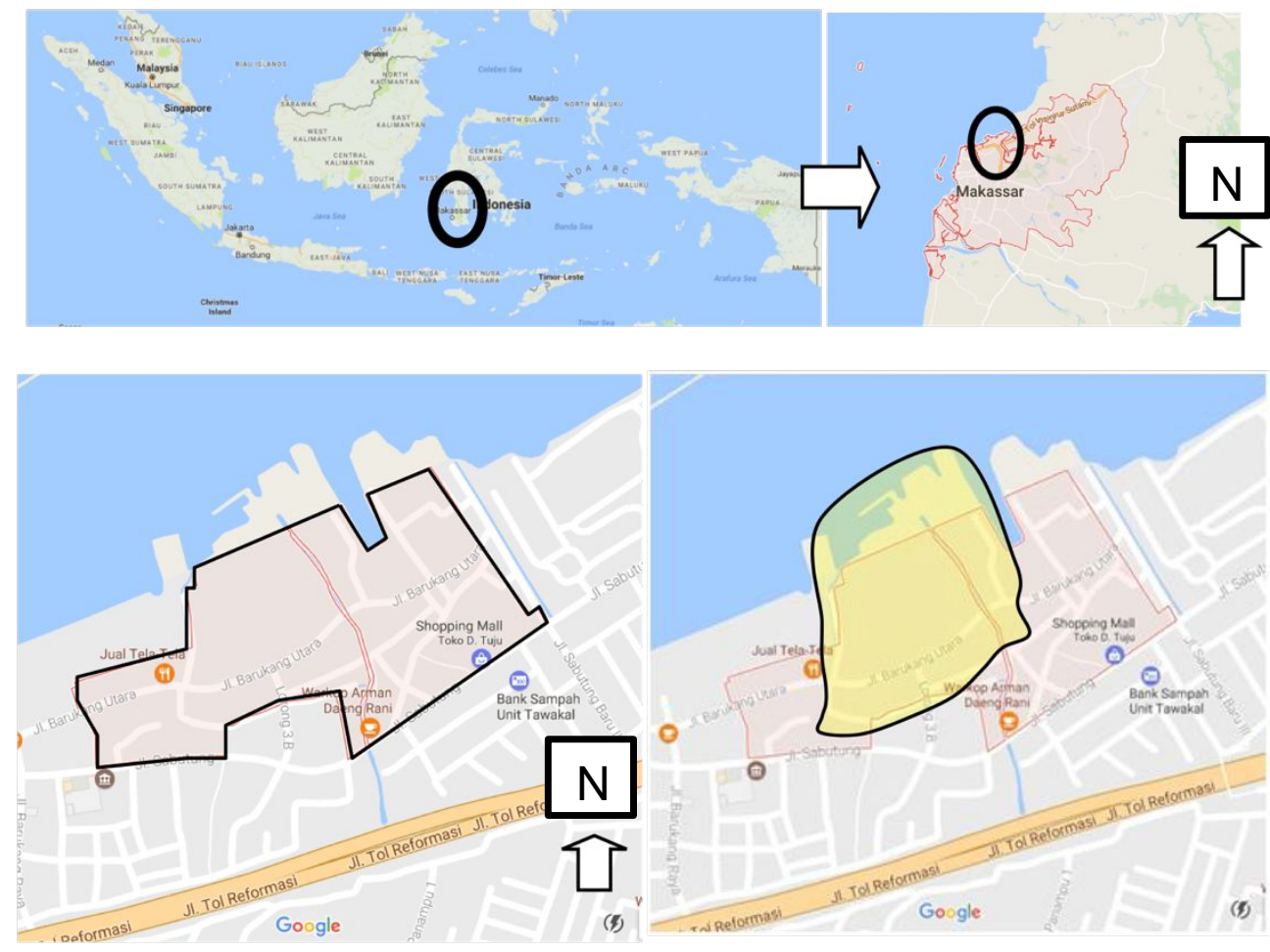

Figure 1. (Top) Location of Cambayya Sub District; (Below) Location of RW 4. Kelurahan Cambayya

The left figure is the boundary of the research area that is the north part bordering the strait of Makassar, the east with PT IKI (ship industry company Indonesia), the south with Barukang street, and the west with Ujung tanah subdistrict. The right figure is the selected location RW 4 (the representation of the government in the kelurahan that consists of approximate $4 \mathrm{RW}$ ) 


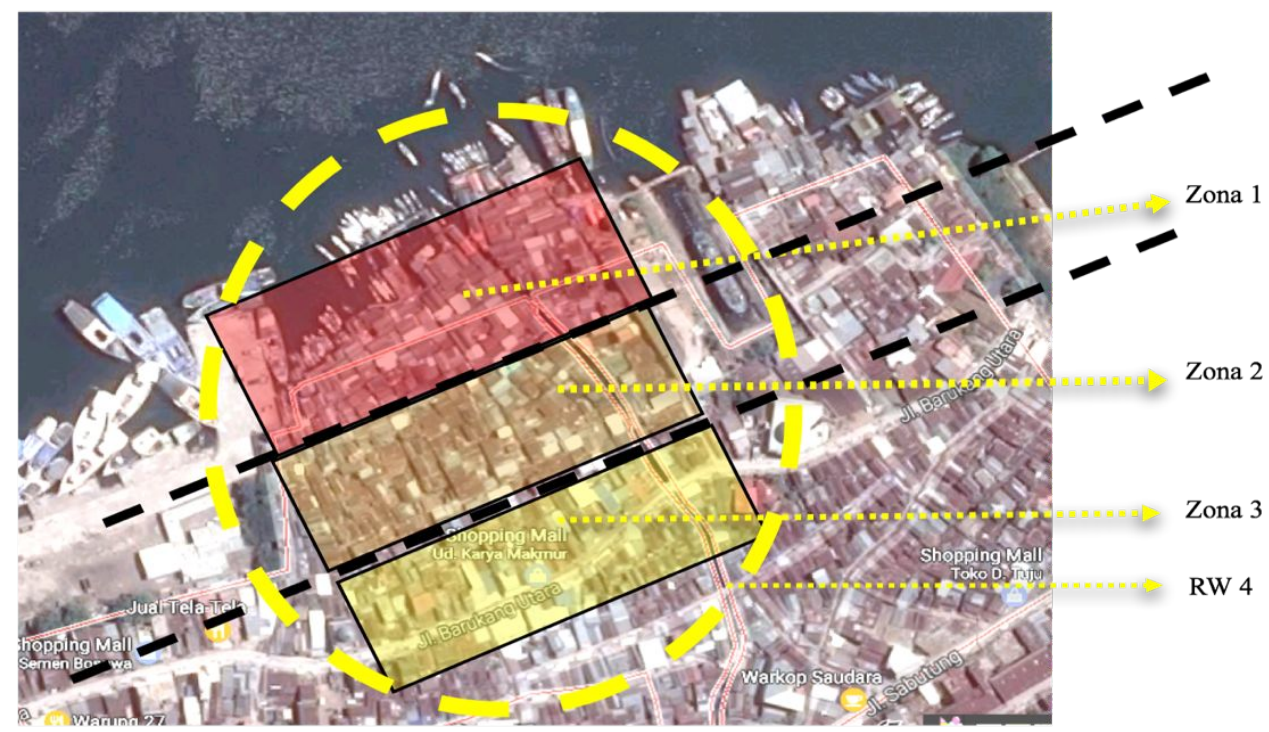

Figure 2. Zone Division of Research Area

Each zone is sampled as many as 20 people each one representing the head of the family. In each zone there are approximately 120 houses. In one house can be inhabited by more than one family.

\section{Zona 1}

\section{a. Houses}

The zone 1, homes are generally built on water, some built on reclaimed land. Housing has an elongated pattern following the beach shape, solid, irregular, and dirty kolong (space under the house) filled with garbage. Housing and environment conditions in zone 1 can be seen in Figure 3.

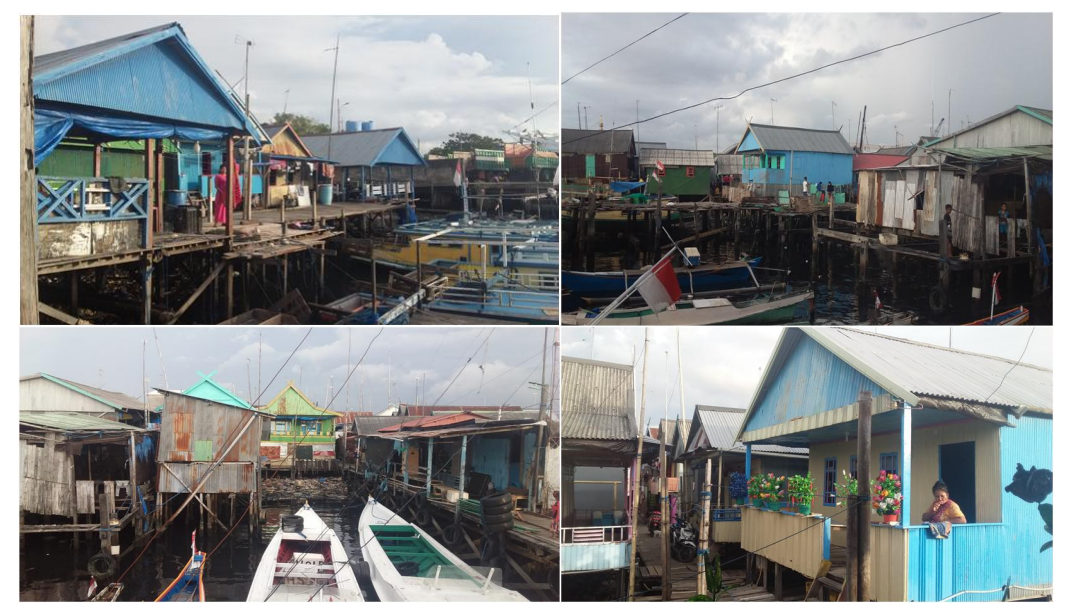

Figure 3. (Continuance) Physical Building Condition in Zone 1 
The building shape is the raised-floor structure. The house terrace adjacent to the Makassar Strait also functions as a dock, boat mooring, and drying fish or other marine products. Generally, the house wall is a combination of zinc and board. The road used is a boarding bridge with a width of $1 \mathrm{~m}$ that can only be passed by pedestrians, motorcycles, and bicycle. The housing pattern is generally irregular. Based on the figure 3, the existing condition of houses in zone one is generally partly uninhabitable house and the house size is not in accordance with the residents number of the house, one of them caused by the lack of their financial ability to build a decent home or to buy land owned by the government. The structure of the house in zone one is a general emergency and semi-permanent.

\section{b. Facilities}

\section{Street}

There is a walkway as the access between houses looks very inadequate, width varies between $75 \mathrm{~cm}-1 \mathrm{~m}$. made of wood and bamboo (Figure 4).
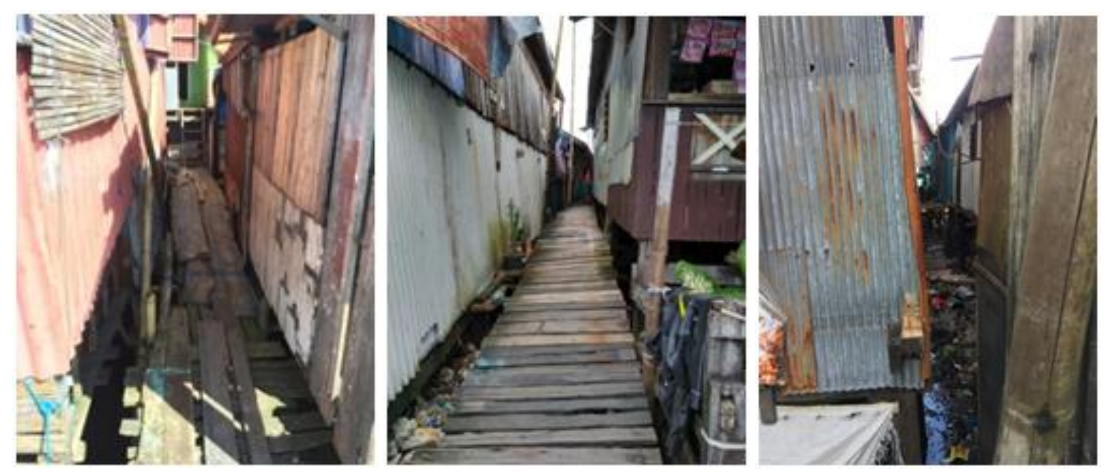

Figure 4. Path Condition

The path can only be passed by motorcycle and pedestrian, using wood material and narrow width. Sometimes people use it to take a bath. The distance from house to house is very narrow, we found among $50 \mathrm{~cm}$ until $1.20 \mathrm{~m}$.

The material is used zinc or board with unplanned shape and looks very simple, material types and conditions are not important, for the community the most important is they have a shelter that can be a protection for the family and rest from the daily routine. It is seen generally used on the side and rear walls.

\section{Sanitation}

Neighborhood settlements in this zone look dirty with garbage floating in the underside of the house. At some points there are public toilets (fell free Water Closet) used by local residents for metabolic needs. Being for bathing activities they do above the wooden bridge near the house (Figure 5). 

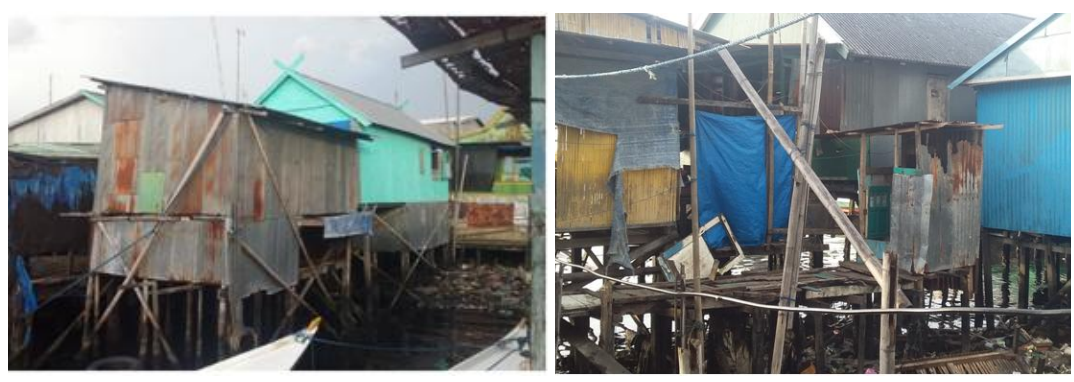

Figure 5. The Sanitation Condition

\section{c. Demographics data}

The following data (Table 1) shows the house size, occupation of houses, ownership status, and number of family members who live in one house.

Table1. The House size, Occupation, Land Ownership Status, and the Number of Households Heads

\begin{tabular}{|c|c|c|c|c|}
\hline No. & $\begin{array}{l}\text { the number } \\
\text { of } \\
\text { households } \\
\text { heads (KK) }\end{array}$ & Occupation & House Size & $\begin{array}{l}\text { Ownership } \\
\text { status }\end{array}$ \\
\hline 1 & $1 \mathrm{KK}$ & Urban village head & $\begin{array}{l}14 \times 3 \mathrm{~m}=42 \\
\mathrm{~m}^{2}\end{array}$ & Personal \\
\hline 2 & $1 \mathrm{KK}$ & Fishermen & $5 \times 7 \mathrm{~m}=35 \mathrm{~m}^{2}$ & Government \\
\hline 3 & $2 \mathrm{KK}$ & Labor and Fishermen & $\begin{array}{l}5 \times 13 \mathrm{~m}=45 \\
\mathrm{~m}^{2}\end{array}$ & Government \\
\hline 4 & $2 \mathrm{KK}$ & Labor and Fishermen & $7 \times 8 \mathrm{~m}=42 \mathrm{~m}^{2}$ & Government \\
\hline 5 & $1 \mathrm{KK}$ & Fishermen & $4 \times 5 \mathrm{~m}=20 \mathrm{~m}^{2}$ & Government \\
\hline 6 & $1 \mathrm{KK}$ & Fishermen & $3 \times 7 \mathrm{~m}=21 \mathrm{~m}^{2}$ & Government \\
\hline 7 & $1 \mathrm{KK}=5$ & Fishermen & $8 \times 7 \mathrm{~m}=42 \mathrm{~m}^{2}$ & Personal \\
\hline 8 & $1 \mathrm{KK}=5$ & $\begin{array}{l}\text { Living cost from } \\
\text { children }\end{array}$ & $4 \times 8 \mathrm{~m}=32 \mathrm{~m}^{2}$ & Personal \\
\hline 9 & $1 \mathrm{KK}=4$ & Fishermen & $\begin{array}{l}5 \times 11 \mathrm{~m}=55 \\
\mathrm{~m}^{2}\end{array}$ & Government \\
\hline 10 & $1 \mathrm{KK}=4$ & $\begin{array}{l}\text { Living cost from the } \\
\text { child }\end{array}$ & $3 \times 7 \mathrm{~m}=21 \mathrm{~m}^{2}$ & Government \\
\hline 11 & $1 \mathrm{KK}=6$ & $\begin{array}{l}\text { Living cost from the } \\
\text { child }\end{array}$ & $9 \times 7 \mathrm{~m}=63 \mathrm{~m}^{2}$ & Government \\
\hline 12 & $1 \mathrm{KK}=7$ & Fishermen & $\begin{array}{l}8 \times 15 \mathrm{~m}=90 \\
\mathrm{~m}^{2}\end{array}$ & Personal \\
\hline 13 & $1 \mathrm{KK}=2$ & Fishermen & $6 \times 5 \mathrm{~m}=30 \mathrm{~m}^{2}$ & Heritage \\
\hline 14 & $1 \mathrm{KK}=3$ & Fishermen & $6 \times 5 \mathrm{~m}=30 \mathrm{~m}^{2}$ & Government \\
\hline 15 & $1 \mathrm{KK}=7$ & Labor & $\begin{array}{l}6 \times 15 \mathrm{~m}=90 \\
\mathrm{~m}^{2}\end{array}$ & Personal \\
\hline 16 & $1 \mathrm{KK}=4$ & Fishermen & $6 \times 7 \mathrm{~m}=42 \mathrm{~m}^{2}$ & Government \\
\hline 17 & $1 \mathrm{KK}=1$ & Selling stalls & $4 \times 3 \mathrm{~m}=12 \mathrm{~m}^{2}$ & Government \\
\hline 18 & $1 \mathrm{KK}=4$ & Fishermen & $6 \times 6 \mathrm{~m}=36 \mathrm{~m}^{2}$ & Government \\
\hline
\end{tabular}


Table1. The House size, Occupation, Land Ownership Status, and the Number of Households Heads (continued)

\begin{tabular}{lllll}
\hline No. & $\begin{array}{l}\text { the number } \\
\text { of } \\
\text { households } \\
\text { heads (KK) }\end{array}$ & Occupation & House Size & $\begin{array}{l}\text { Ownership } \\
\text { status }\end{array}$ \\
\hline 19 & $1 \mathrm{KK}=2$ & Pedicab driver & $3 \times 6 \mathrm{~m}=18 \mathrm{~m}^{2}$ & Government \\
20 & $1 \mathrm{KK}=4$ & Fish auction & $5 \times 7 \mathrm{~m}=35 \mathrm{~m}^{2}$ & Government \\
21 & $1 \mathrm{KK}=6$ & Fishermen & $6 \times 12 \mathrm{~m}=72$ & Government \\
& & & $\mathrm{m}^{2}$ & \\
22 & $1 \mathrm{KK}=1$ & Peddler & $2,5 \times 6 \mathrm{~m}=18 \mathrm{~m}^{2}$ & Personal \\
23 & $1 \mathrm{KK}=3$ & Security & $6 \times 6 \mathrm{~m}=36 \mathrm{~m}^{2}$ & Personal \\
\hline
\end{tabular}

Generally, the occupied land is owned by the government inhabited by fishermen and laborers, the building measuring between $30-44 \mathrm{~m}^{2}$.

\section{d. Activities}

There are various activities undertaken by society in zone 1, the activities are shown in Figure 5.
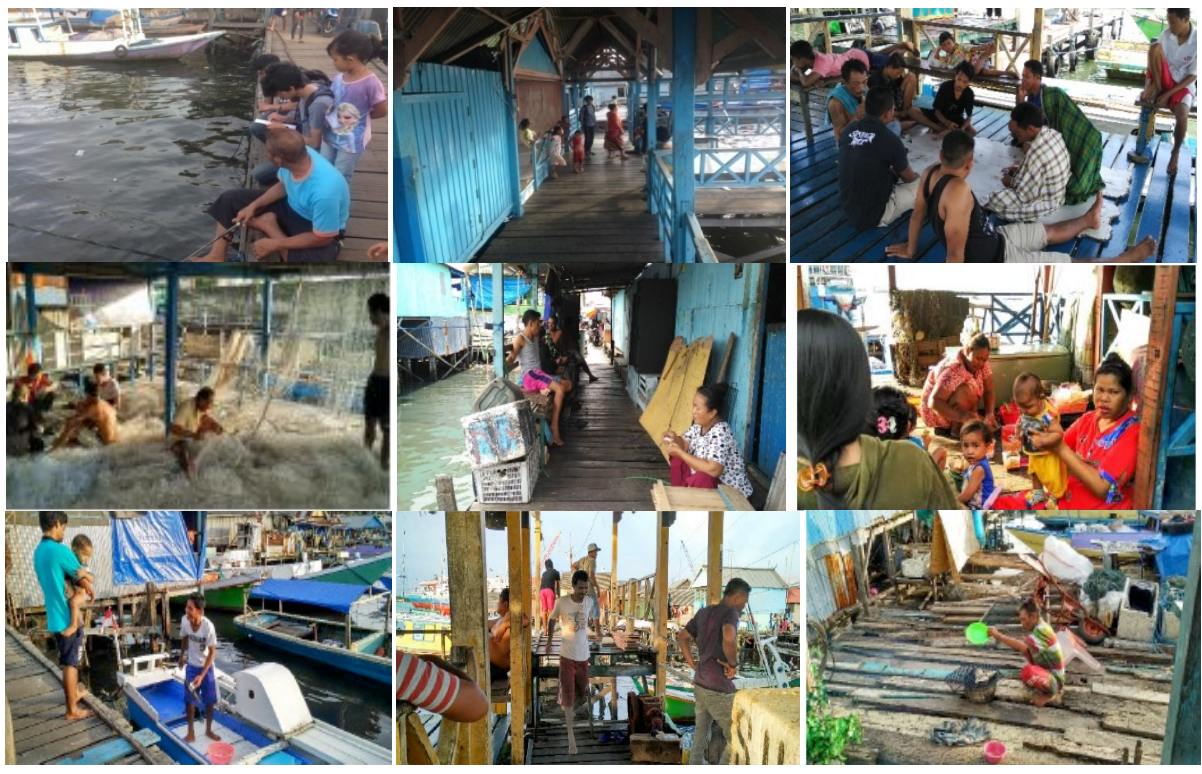

Figure 5. The Activities at Zone 1

Various activities carried out by communities in zone 1 are centered on the pier, whether done by men, women or children. Men's activities are generally related to work as a fisherman, while women and children are generally only associated with leisure activities while doing interaction. 


\section{Zona 2}

\section{a. Houses}

In the 2 nd zone, the buildings are erected on a coastal border, the land has been dumped before building a house. The houses in this zone can be seen in Figure 6 .

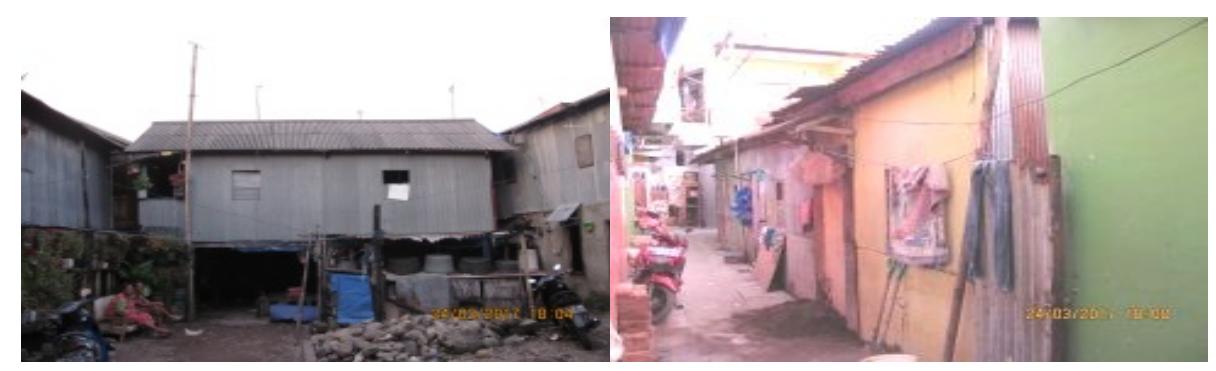

Figure 6. Physical Condition of Housing

The houses located in zone 2 have 2 types, most of which is onland house type and only a small part is raised-floor structure house. The material used is also various kinds, there is material of zinc, wood, and stone or combination among them.

\section{b. Facilities}

\section{Street}

The street condition of the housing environment in zone 2 is shown in figure 7.
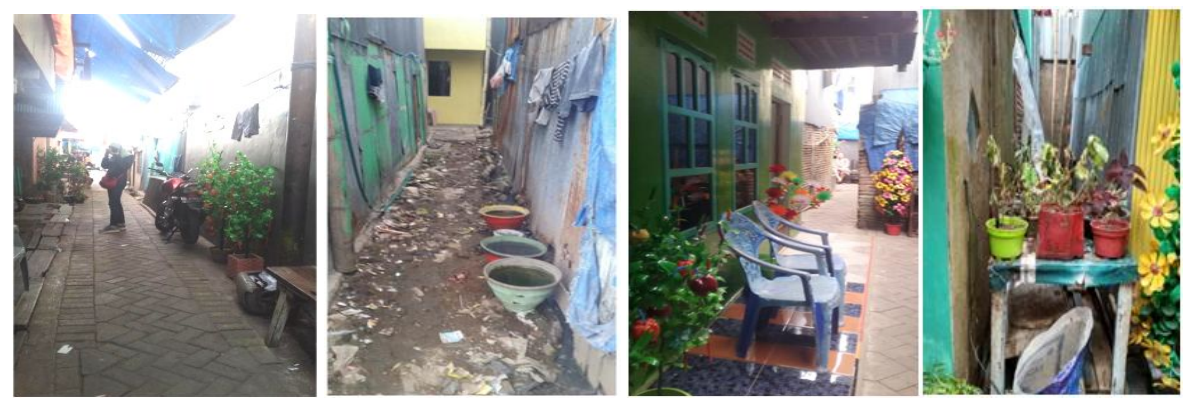

Figure 7. Street Condition

The path in zone 2 is wider, the size between $1.5-2 \mathrm{~m}$. materials generally use paving block, only a small part of it is still a soil street. part of the street is decorated with plastic flowers handicrafts from housewives in the area. The path in addition to functioning as a circulation area as well as an area of interaction, play, selling for the surrounding residents. 


\section{Sanitation}

The sanitation facilities in zone 2 are inadequate. Water closet (WC) is located in each resident's house and there are no public toilets in the neighborhood. While the dirty water network flowed on the path side with unfeasible conditions (shallow and narrow), the dirty water flow is directed to the sea.

\section{c. Demographics Data}

Table 2. The House size, Occupation, Land Ownership Status, and the Number of Households Heads

\begin{tabular}{lllll}
\hline No. & $\begin{array}{l}\text { The number of } \\
\text { households heads } \\
\text { (KK) }\end{array}$ & Occupation & House Size & $\begin{array}{l}\text { Ownership } \\
\text { land status }\end{array}$ \\
\hline $\mathbf{1}$ & $1 \mathrm{KK}$ & Fishermen & $5 \times 6 \mathrm{~m}=30$ & Government \\
$\mathbf{2}$ & $1 \mathrm{KK}$ & Selling vegetables & $7 \times 9 \mathrm{~m}=63$ & Government \\
$\mathbf{3}$ & $1 \mathrm{KK}$ & Fishermen & $5 \times 5 \mathrm{~m}=25$ & Government \\
$\mathbf{4}$ & $1 \mathrm{KK}$ & Labor & $12 \times 4 \mathrm{~m}=48$ & Government \\
$\mathbf{5}$ & $1 \mathrm{KK}=3$ org & Selling fish & $3 \times 11 \mathrm{~m}=33$ & Contract \\
$\mathbf{6}$ & $2 \mathrm{KK}=7$ org & Labor & $3 \times 11 \mathrm{~m}=33$ & Contract \\
$\mathbf{7}$ & $1 \mathrm{KK}=2$ org & Labor & $3 \times 11 \mathrm{~m}=33$ & Contract \\
$\mathbf{8}$ & $2 \mathrm{KK}=7$ org & Labor & $11 \times 7 \mathrm{~m}=77$ & Government \\
$\mathbf{9}$ & $1 \mathrm{KK}=4$ org & Fishermen & $7 \times 4 \mathrm{~m}=28$ & Heritage \\
$\mathbf{1 0}$ & $1 \mathrm{KK}=4$ org & Driver & $4 \times 5 \mathrm{~m}=20$ & Personal \\
$\mathbf{1 1}$ & $2 \mathrm{KK}=5$ org & Labor & $4 \times 5 \mathrm{~m}=20$ & Personal \\
$\mathbf{1 2}$ & $1 \mathrm{KK}=6$ org & Security & $4 \times 7 \mathrm{~m}=28$ & Government \\
$\mathbf{1 3}$ & $1 \mathrm{KK}=5$ org & Carbroker & $6 \times 12 \mathrm{~m}=72$ & Government \\
$\mathbf{1 4}$ & $1 \mathrm{KK}=4$ org & Labor & $4 \times 7 \mathrm{~m}=28$ & Personal \\
$\mathbf{1 5}$ & $1 \mathrm{KK}=6$ org & Fishermen & $5 \times 8 \mathrm{~m}=40$ & Government \\
$\mathbf{1 6}$ & $1 \mathrm{KK}=4$ org & selling stalls & $4 \times 6 \mathrm{~m}=24$ & Personal \\
$\mathbf{1 7}$ & $1 \mathrm{KK}=6$ org & Fishermen & $4 \times 5 \mathrm{~m}=20$ & Government \\
$\mathbf{1 8}$ & $2 \mathrm{KK}=4$ org & Fishermen & $7 \times 6 \mathrm{~m}=42$ & Government \\
$\mathbf{1 9}$ & $1 \mathrm{KK}=6$ org & Labor & $7 \times 6 \mathrm{~m}=62$ & Heritage \\
\hline
\end{tabular}

In zone 2, in one house there are 2 household heads, more varied livelihoods, land tenure status is no longer dominated by the government

\section{d. Activities}

In zone 2, community activities are not different from those occurring in zone 1. People generally have activities on the road. The activity can be seen in Figure 8. 


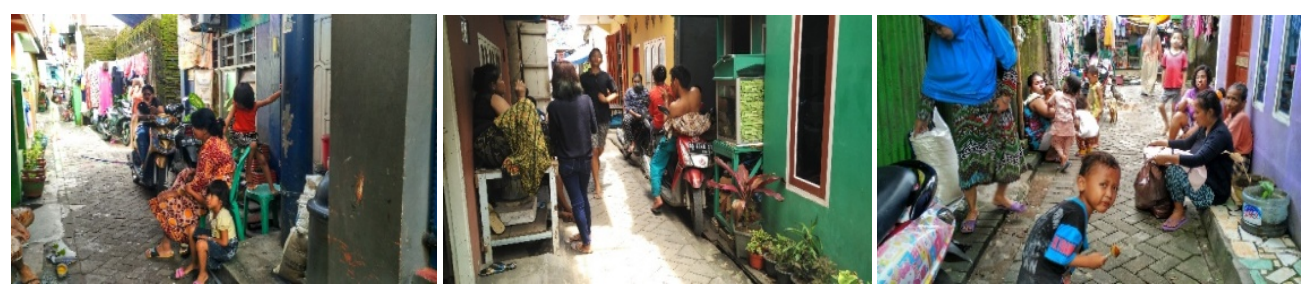

Figure 8. Community Activities in Zone 2

The relaxed activities and social interactions of men, women and children generally take place on the street in front of their homes.

\section{Zona 3}

In zone 3 , houses are not construct on coastal border, but in the proper place.

\section{a. Houses}

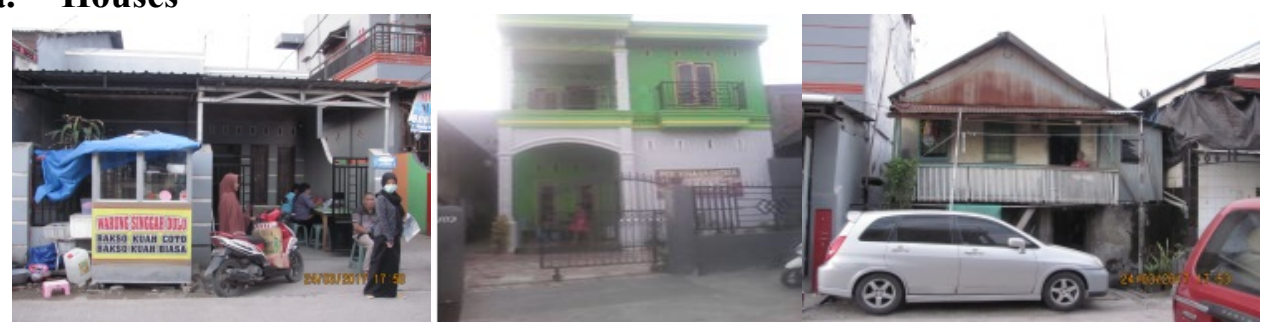

Figure 9. Forms of Houses Adjacent to the Main Road (jalan Barukang)

Generally, houses are onland type, with stone material. Some houses, especially those bordered directly by the main road, built two-story and using brick material, but not denied if there is also a house in the form of semi-permanent in the zone (Figure 9).

\section{b. Facilities}

\section{Street}

In general, the width of the road in zone 3 is approximately $1 \mathrm{~m}$ to $2.5 \mathrm{~m}$, and no longer found dirt road. In zone 3 the distance between houses range $10 \mathrm{~cm}$ or even up to $1 \mathrm{~m}$ (Figure 10).

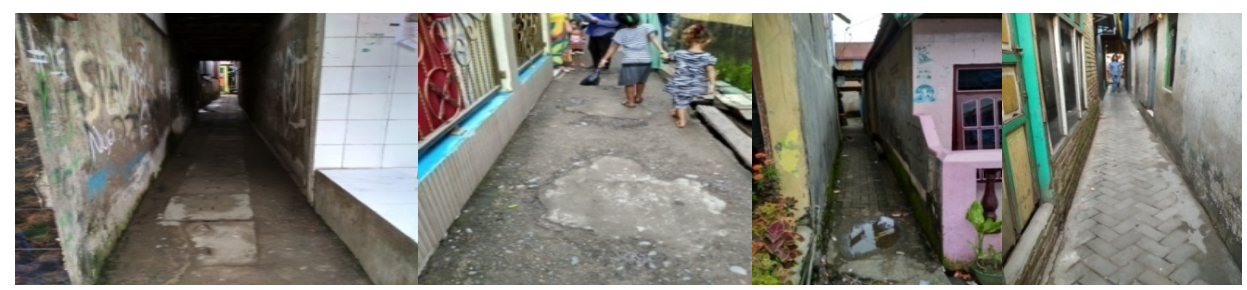

Figure 10. Physical Condition of Street 


\section{c. Demographics Data}

Table 3. The House size, Occupation, Land Ownership Status, and the Number of Households Heads.

\begin{tabular}{|c|c|c|c|c|}
\hline No. & $\begin{array}{l}\text { the number } \\
\text { of } \\
\text { household's } \\
\text { heads (KK) }\end{array}$ & Occupation & House Size & $\begin{array}{l}\text { Ownership } \\
\text { land status }\end{array}$ \\
\hline 1 & $1 \mathrm{KK}$ & Labor & $\begin{array}{l}6,5 \times 4,5 \mathrm{~m} \\
=29.25\end{array}$ & Heritage \\
\hline 2 & $1 \mathrm{KK}$ & Installment Business & $13 \times 7 \mathrm{~m}=91$ & Government \\
\hline 3 & $1 \mathrm{KK}$ & Mechanic & $3 \times 7 \mathrm{~m}=21$ & Government \\
\hline 4 & $2 \mathrm{KK}$ & Grocery Store & $8 \times 10 \mathrm{~m}=80$ & Government \\
\hline 5 & $1 \mathrm{KK}$ & Entrepreneur & $7 \times 10 \mathrm{~m}=70$ & Personal \\
\hline 6 & $2 \mathrm{KK}$ & Teacher & $5 \times 5 \mathrm{~m}=25$ & Personal \\
\hline 7 & $1 \mathrm{KK}$ & Entrepreneur & $18 \times 20 \mathrm{~m}=360$ & Personal \\
\hline 8 & $2 \mathrm{KK}$ & Entrepreneur & $8 \times 17 \mathrm{~m}=136$ & Personal \\
\hline 9 & $1 \mathrm{KK}=7$ org & Labor & $5 \times 10 \mathrm{~m}=50$ & Personal \\
\hline 10 & $1 \mathrm{KK}=1$ org & Grocery Store & $5 \times 5 \mathrm{~m}=25$ & Personal \\
\hline 11 & $1 \mathrm{KK}=5$ org & Labor & $4 \times 5 \mathrm{~m}=20$ & Personal \\
\hline 12 & $1 \mathrm{KK}=1$ org & Selling & $4 \times 5 \mathrm{~m}=20$ & Government \\
\hline 13 & $1 \mathrm{KK}=4$ org & Tailor & $4 \times 6 m=24$ & Government \\
\hline 14 & $1 \mathrm{KK}=5$ org & Labor & $34 \times 6 \mathrm{~m}=24$ & Government \\
\hline 15 & $1 \mathrm{KK}=5$ org & Fishermen & $3 \times 7 \mathrm{~m}=21$ & Government \\
\hline 16 & $1 \mathrm{KK}=4 \mathrm{org}$ & Fishermen & $6 \times 6 \mathrm{~m}=36$ & Personal \\
\hline 17 & $1 \mathrm{KK}=5$ org & Civil Servants & $11 \times 12 \mathrm{~m}=132$ & Personal \\
\hline 18 & $1 \mathrm{KK}=4$ org & Selling & $12 \times 7 \mathrm{~m}=84$ & Government \\
\hline 19 & $2 \mathrm{KK}=7$ org & Construction Workers & $11 \times 5 \mathrm{~m}=55$ & Government \\
\hline 20 & $1 \mathrm{KK}=2$ org & Fishermen & $5 \times 8 \mathrm{~m}=40$ & Government \\
\hline 21 & $2 \mathrm{KK}=6$ org & Entrepreneur & $7 \times 6 m=42$ & Government \\
\hline 22 & $1 \mathrm{KK}=6$ org & Fishermen & $3 \times 7 \mathrm{~m}=21$ & Government \\
\hline
\end{tabular}

Can be seen in table 3 , in zone 3 generally residential land of the residents belong to the government, even though already many of the residents can buy the land. One of the reasons is because the location of their settlement is not directly adjacent to the sea, so they feel safe enough to stay for a long time. In addition, the economic level of citizens in zone 3, is sufficient. Generally, in zone 3 local people's livelihood is very diverse. Many residents open business in front of their houses. Like for example they open a food stall, internet cafe, and there is also selling clean water. This is due to the location of their residence directly connected to the main road in kelurahan Cambaya, although not a few who still work as fishermen and laborers. We can see in the table 2 the survey results, namely the area of the building in zone 3 is dominated by a wide range of $15-45 \mathrm{~m} 2$. Many of the residents are already able to have a much wider house. Even among them, there are already a few houses of sufficient size, adequate for them to live in. 


\section{d. Activities}
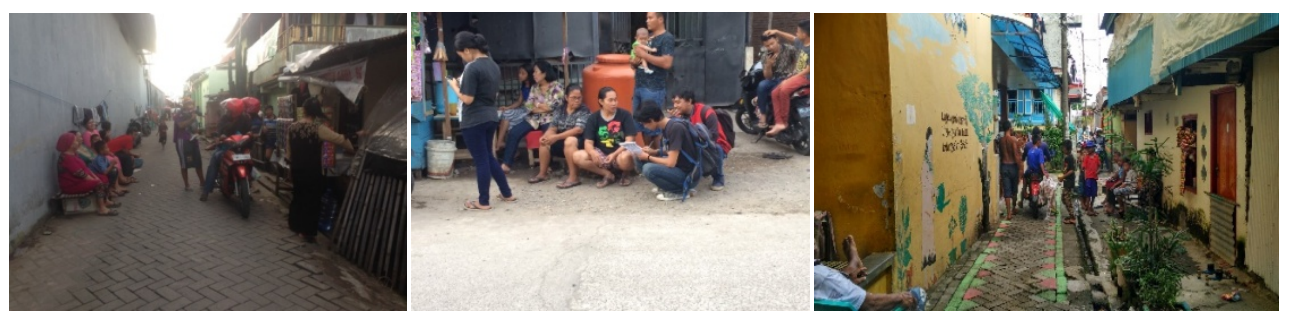

Figure 11. Street Activities at the Zone 3

Activities of children and women and men are generally done on the street

\section{THEORY / RESEARCH METHODS}

Mix use method was used in this research. Physical data were taken through recording and deep observation. Physical data includes housing conditions, which include houses and materials, road and sanitation networks, and building distances. While non-physical data include the type of work, land ownership status, the number of household heads in the house, and the width of the house. Non-physical data is numerical and is taken randomly on every family. Data collection is divided into 3 zones, and each zone averages 20 families. Determination of respondents using random sampling method.

The interview process was performed with non-participation observation (Sugiyono, 2006), where the data of the research were analyzed and presented using descriptive statistical analysis technique.

\section{RESULTS AND DISCUSSION}

The following Figure 12 shows the differences land ownership in each zone in the study area

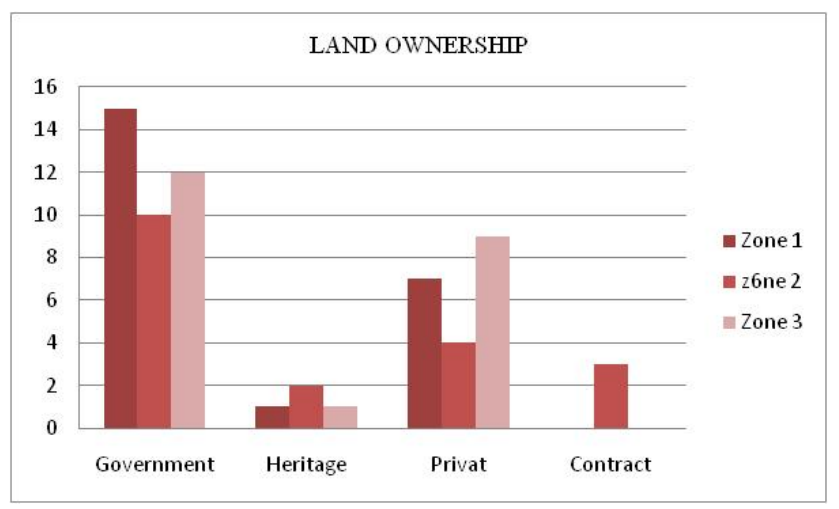

Figure 12. Land Ownership 
As noted in the figure 12, that is, the ownership of the community's residence. Cambaya is still dominated by government-owned land. Although not a few of the residents are able to buy their own land. Figure 13 shows the occupation of the residents and Figure 14 shows the house size.

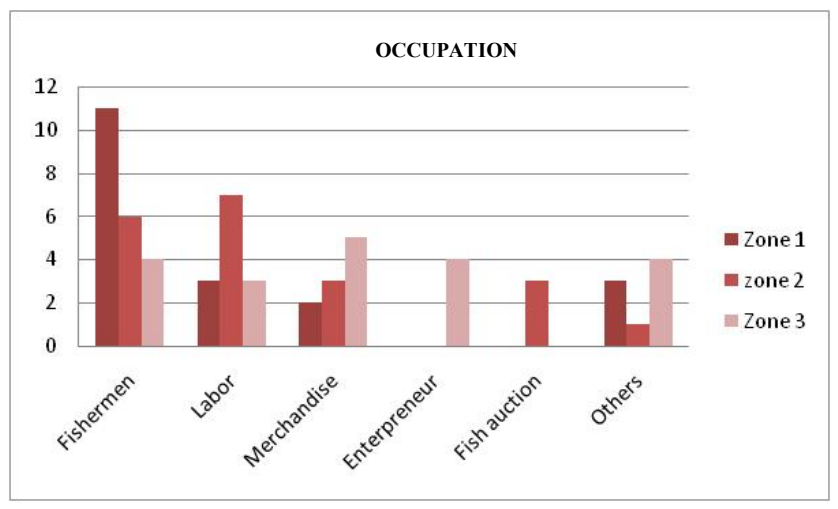

Figure 13. Occupation

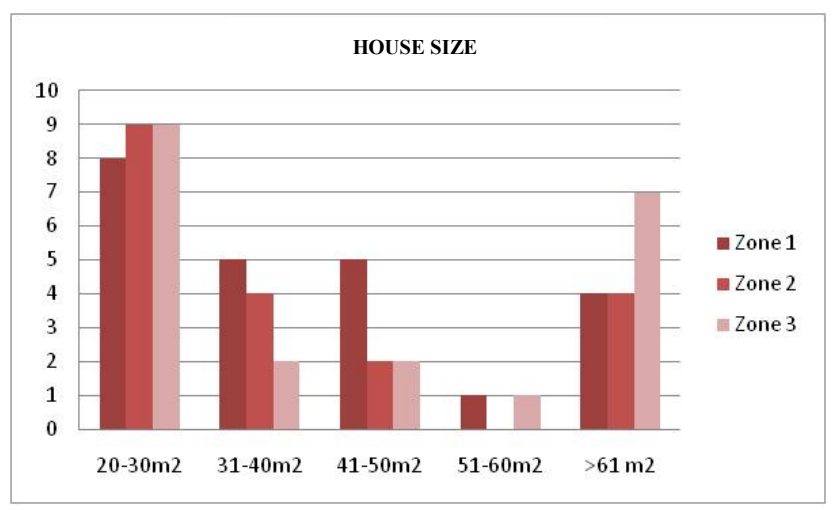

Figure 14. House size

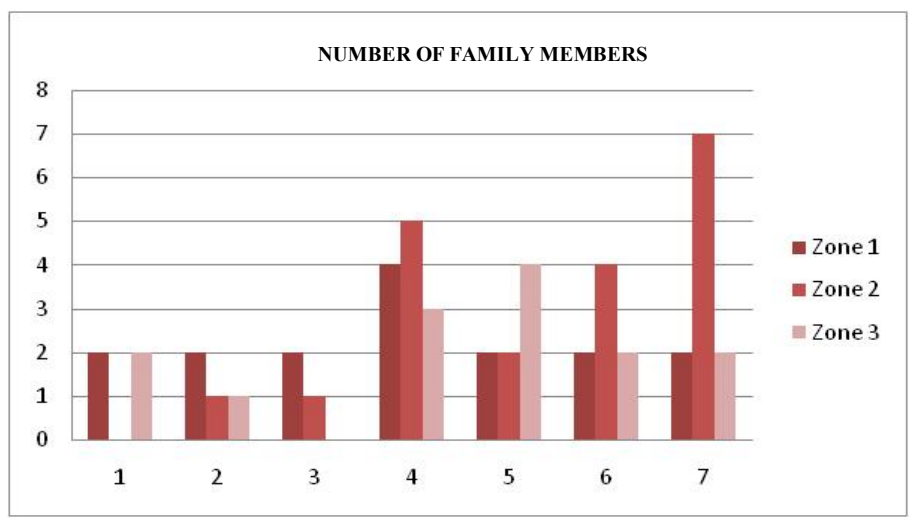

Figure 15. Number of family members 
Figure 15 shows the number of family members. Cambayya generally inhabited by people who work as fishermen and laborers. The location of the houses is getting closer to the sea, the occupation of occupants is dominated by fishermen, while in zone 2 is more dominated by labor and in the $3 \mathrm{rd}$ zone, is dominated by trade sector.

Considering the field conditions, the area of RW 4 included in the category of wild settlements, As mentioned confirmed by Srinivas (2007), he defines wild settlement based on 3 characters, namely physical character, social, legal. In the area of RW 4, these three characters were found. Those facilities are very limited and with a very minimal quality. Generally low levels of income (fishermen and workers), and legal because most households are established on real government land, not for residential purposes.

Although the area occupied by the government and illegal for habitation, but the community, especially fishermen and laborers still choose the place as a residential locality. This is understandable because according to UN-HABITAT (2008) the poor in their efforts to get home, the proximity to the workplace and job opportunities are a major factor in the consideration of choosing a place to live. The proximity to markets, factories, business areas, transport networks and construction sites means greater income, higher employment opportunities, and lower transportation costs. RW 4 is a support area for fishermen and laborers because this area is directly adjacent to the sea as a fisherman's workplace and also close to the port as a workplace for transport workers.

Fishermen and laborers are professions with low income. The link between income level (economic status) and the space of settlements and houses are described in several theories and concepts as Suparlan (1978) says that the house form is determined by economic affordability and cultural influence, which will also affect the physical form of the settlement environment. Meanwhile, according to Smith (in Budihardjo, 1985), low-income communities place site selection near employment as the main preference, then following the status of location and finally the provision of social facilities and convenience. This is in contrast to the upperincome group preference / priority in the field of housing with income level of society can be seen in the following Figure 16 .
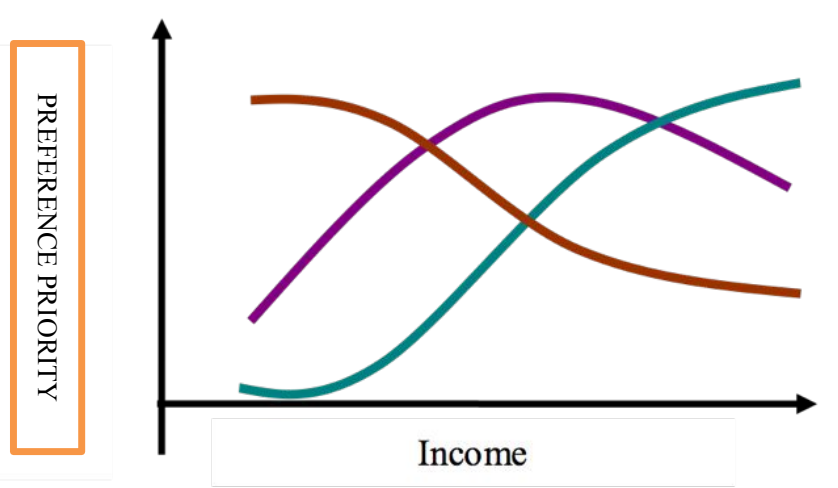

\author{
Social facilities and comfort \\ ownershin status \\ Locations near to the \\ employment
}

Figure 16. The Relationship between Income and Priority Preference 
The Turner Theory (1972) also sees a connection between income abd preference priority, which in addition to income, location, and land positions, the cycle of life (age) also plays a role in that, this can be seen in Figure 17.

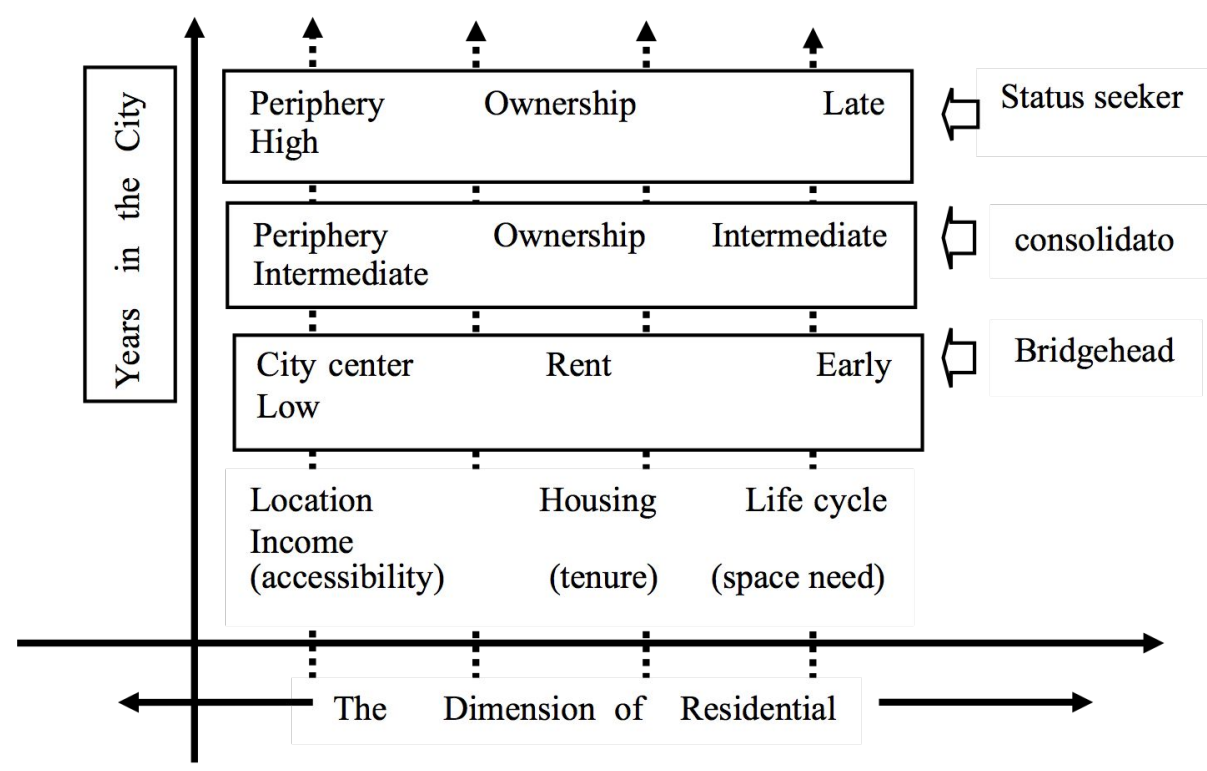

Figure 17. The Role of the Cycle of Life (age)

Associated with the income seen in the figure that the higher of personal income level, then the status of land ownership will be increasingly prioritized. The location of housing will be further away from work. While the study of the lower society demands in the house form revealed by Gans $(1978 ; 29)$ in Budiharjo (1987) says "lower class people do not demand a beautiful and unique permanent home, yet expect adequate space to accommodate their life activities. the relationship between work and location of settlements expressed by Mulyadi (2007) in Idawarni (2013) that they (fishermen) generally live on the beach, close to the location of their activities, so it is not surprising that they live in areas directly adjacent to water.

Based on the Figure 12,13, 14, informing that zones 1 and 2 people work is dominated as fishermen and unskilled laborers, the house size is generally between 20 $50 \mathrm{~m}^{2}$ and occupied on average between 4-7 people in one housing unit. The three mentioned factors have a relationship, as expressed in the following concepts: The number of families is an important factor affecting household poverty (eg Chemichovsky Dan Meesok, 1984; Sigit, 1985; Alamgir and Ahmed, 1988; Kuznets, 1989; Gaiha , 1989, Firdaussy, 1992) in Agunggunanto (2011). A large number of families will automatically affect the real consumption level of family members, which means the expenditure is also large, but it is not accompanied by high family income. Because fishermen and laborers dominating zones 2 and 3 are low-income groups, as Satria (2009) notes, the fishing community is the poorest of the poor. Informal sector workers such as laborers and fishermen are perceived as blue-collar workers as workers on jobs that rely on physical strength, which thus requires no skills and higher education. 
Fishermen and unskilled laborers have generally low education levels. Payung Bangun (1997) said that one of the poverty causes which is the life of some people related to the quality of human resources (HR) is low level. Therefore, it is not possible to have the ability to respond adequately to the challenges that must be faced in life (Kuemba, 2012).

A high family size, low incomes, and low human resources (low levels of education and skills) are the factors that cause poverty. Poverty of the community in the research area can be seen in the condition of housing material and land ownership.

\section{CONCLUSION}

The choice of residential location is strongly influenced by work and income. Lower class people often place occupancy on illegal land, due to the insistence on the need for shelter. The illegal lands are generally close to the location of the work. The arrangement of residential space is affected by the availability of land, land position, occupation and the number of families. Employment is a major factor in choosing residential locations for the low economically, while the land position as a government property gives the community greater opportunity to build shelter than on one's own land, the size of the occupancy is heavily dependent on land availability and economic capacity. This can be seen in zone 1 adjacent to the sea, the width of the houses is not affected by the type of work, but the initial opportunity to build a house. Materials and construction used are the emergencies, this is to facilitate residents to dismantle their homes if the government wants to immediately take over the land.

\section{REFERENCES}

Idawarni (2013), Temu Ilmiah IPLBI 2013. Prosiding Temu Ilmiah IPLBI 2013, Makassar: Universitas Hasanudin

Srinivas, H. (2007), Defining Squatter Settlement, Urban Squatters and Slums, (http://www.gdrc.org/uem/squatters/define-squatter.html-19k)

UN-HABITAT. (2008,. Quick Guide for Policy Makers No.4. Eviction: Alternatives to the whole Scale Destruction of Urban Poor Communities Nairobi: UNESCAP dan UN-HABITAT.

UN-HABITAT. (2008), Quick Guide for Policy Makers No.2. Low-Income Housing: Approaches to Help the Urban Poor Find Adequate Accommodation. Nairobi: UNESCAP dan UN-HABITAT.

Suparlan, P. (1987), Tinjauan Tentang Kampung kota, Pusat Informasi P2KP.

Budihardjo, E. (2006), Percikan Masalah Arsitektur, Perumahan Perkotaan, Cetakan terbaru, Gadjah Mada University Press. 
Turner, J.F. (1972), Freedom to Build. Dweller Control of Housing Process. Publisher The Macmillan Company, USA.

Agunggunanto, E.Y. (2011), Analisis Kemiskinan Dan Pendapatan Keluarga Nelayan Kasus Di Kecamatan Wedung Kabupaten Demak, Jawa Tengah, Indonesia. Jurnal Dinamika Ekonomi Pembangunan, Juli 2011, Volume 1, Nomor 1

Kuemba (2012), Buruh Bagasi Kapal Di Pelabuhan Kota Bitung. Publisher: Jurnal Holistik. Published: 2013-04-20, Holistik, Tahun V No 10A / Juli Desember 2012

Satria, A. (2009), Laut dan Pesisir untuk Kesejahteraan Masyarakat. Bogor: IPB Press

Sugiyono (2006), Metode Penelitian Kuantitatif Kualitatif dan R\&D. Bandung. Alfabeta 